\title{
2.4 New materials and technologies in design
}

Currently, design as an artistic activity synthesizes scientific, technical and humanitarian knowledge. The design of the architectural environment is a generally recognized and priority area in all spheres of human life. The designer-architect is faced with a choice - from what material the project system will be made of and by what technology.

The growth rates of industrial production associated with the development of new technologies and materials are significantly ahead of the terms of their aesthetic development. The contradictions between beauty and functionality continue to deepen, especially in the area of ecology. All this is due to the fact that until now industrial design does not have a coherent theory of the aesthetics of industrial materials and technologies, which, in turn, makes it difficult to train specialists in the field of industrial design.

Recent work in this direction has been solving narrow specific problems and their results are considered only as prerequisites for the creation of such a theory. The need for a permanent solution to this problem determines the relevance of this work.

A systematic approach to solving problems of design of hinged facade systems using historical experience is proposed. A methodology has been developed for the classification of metallic materials for design according to their coloristic and structural properties. The scientific foundations of the design of metal products have been developed from the standpoint of the use of new materials and technologies in their manufacture.

In the middle of the 19th century, the outstanding German theorist of architecture and industrial art, Gottfried Semper (1803-1879), formulated the problem of the connection between aesthetics and technology. He showed that science and technological progress provide at the disposal of artistic practice such materials and methods of their processing that "have not yet been mastered aesthetically." $\mathrm{He}$ believed that the time required for the aesthetic mastering of innovations would be constantly reduced due to the ever-increasing resolution capabilities of technology and 
the increasing artistic experience accumulated with the development of the arts [131]. Semper Gottfried was born in Altona (a city near Hamburg, now its district) on November 29, 1803. Initially he studied law and mathematics at the local university, then studied in the workshops of architects F. Goertner in Munich (1825) and F. Gau in Paris (from 1826) ... In 1830-1833 he traveled to France, Greece and Italy. Professor of the Dresden Academy of Arts (since 1839), took part in the revolution of 1849, after which he was forced to emigrate. Lived in Paris, London (from 1851). In 1855-1871 professor at the Polytechnic and director of the School of Construction in Zurich. In 1871-1876 he worked in Vienna. In his architectural practice he was inspired by the ancient classics, but not in its pure form (as was the case with his friend K.F. Schinkel), but perceived through the prism of the Italian Renaissance and Baroque (Semper, Gottfried (1803-1879), German architect and art theorist, representative of romantic historicism).

Karl Friedrich Schinkel was born in 1871 in the family of an archdeacon. After the death of his father at the age of four, Schinkel moved to the capital and entered the Academy of Architecture. His mentors in the architectural field were David and Friedrich Gilly, the founders of the academy. He combines his studies with work as an artist in a porcelain factory (at first, Schinkel was engaged in painting and lithography). He published a number of theoretical works, the most important of which is the book Style in the technical and tectonic arts (1863) - an experience of "practical aesthetics", where, in contrast to the philosophical idealism of his time, he emphasized the basic style-forming significance of materials and technology. (Karl Friedrich Schinkel - an outstanding architect of German origin at the beginning of the 19th century).

He advocated the activation of the role of color in sculpture and architecture, devoting his scientific works to this problem "Notes on the Painted Architecture and Plastics of the Ancients (1834) and on Polychromes (1851)".

Learning the history of the surrounding world, primitive man had a desire to explain everything around him and everything that happens in himself, i.e. the world as a whole. The ancient people embodied their entire first secret experience in mythology, the most powerful layer of spiritual culture. Generalizations and 
individualization made the myths more artistic. Gradually, an artistic and mythological consciousness arose. The first forms of religion were born.

During the Paleolithic period, fine art was born. The objects of artistic embodiment were, first of all, those objects and natural phenomena that were most closely related to practical activities with the problem of survival.

The accumulation of material and technical experience has led to the emergence in the III millennium BC They arose on the territory of Northeast Africa, Anterior and Central Asia, the Chinese Plain and the Indian subcontinent. The peculiarity of these civilizations was the heterogeneity of the processes of their cultural and historical development. Aesthetic the picture of the world in the era of ancient civilizations is a synthesis of religion, philosophy and "aesthetics", and religious and mythological views played a major role.

At the time of the fall of the Roman Empire, the population of Europe was not homogeneous, and this was reflected in European culture. It absorbed the cultural traditions of the peoples inhabiting Europe, experienced the influence of Antiquity and the East, therefore, we can say that there is no single style in medieval art, there is only a general idea, to which all medieval art is subordinated. This common feature is a deeply mystical, religious character.

At the turn of the XIX - XX centuries. there was a crisis in the system of scientific, aesthetic and ethical values. An attempt is made to generalize the aesthetic experience of mankind, to combine the artistic traditions of the West and East, antiquity and the Middle Ages, classicism and romanticism. The new artistic style was called modern (from the French. Modem, Latin. Modemus - modern).

Ancient China was an important region for the development of metallurgy in Asia. At the turn of 3000-2000. BC. bronze was known on the territory of China. In the 7th century BC. here they began to smelt pig iron. Already at the dawn of the Bronze Age, the Caucasus was a large region of the ancient world for metalworking, supplying neighboring lands with metal products. In the III millennium BC. in Transcaucasia, decorative items were cast using wax models. The early culture of processing copper and precious metals in southeastern Europe is incomparably poorer than in the regions 
considered above. In the 4th century BC. made castings in open and closed molds. In ancient Greece in the classical period (V-IV century BC) bronze statues of deities, heroes, athletes were cast, which were installed in temples, sanctuaries, necropolises and squares [132].

The experience of the Chinese raw material metallurgy is unique. In China and the nearby territories of the Far East, already at the beginning of the 1st millennium BC. e. smelting of pig iron in crucibles was mastered. To obtain cast iron, a charge consisting of blast iron and charcoal was placed in crucibles. Then the crucibles were kept in the hearths for a long time at temperatures above $1200^{\circ} \mathrm{C}$. The gradual dissolution of carbon in iron made it possible to obtain liquid cast iron saturated with carbon from solid crucible iron (in Fig.1).

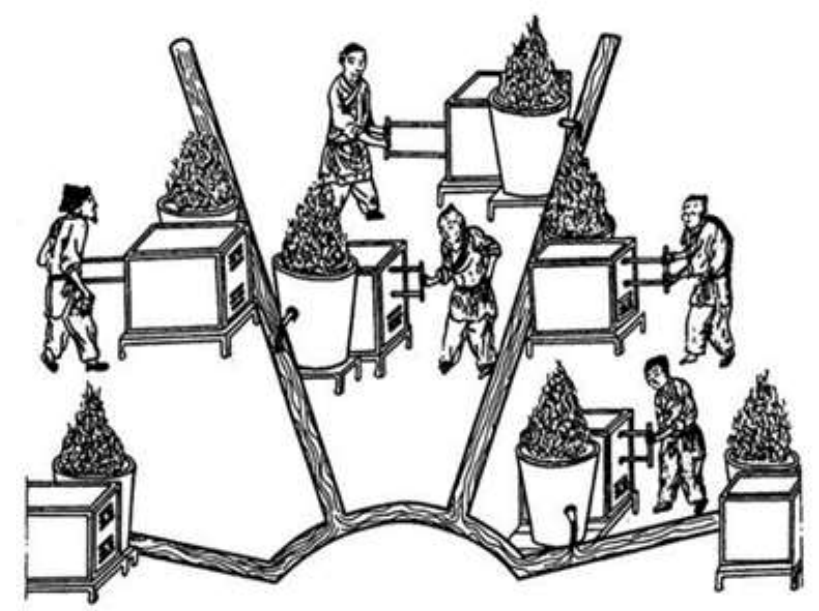

Figure 1. Chinese raw material metallurgy.

In ancient Italy, the Etruscans were skilled casters. Etruscan sculpture is characterized by a subtly expressed sense of plastic form. Monumental and easel sculpture in Ancient Rome of the period republics (V - I centuries BC) and empires (I - V centuries AD) were also located on high level. Particularly significant are the achievements of portraiture plastics.

In the Middle Ages (5th - 15th centuries AD), Byzantine culture is essentially a continuation of the Roman culture. The capital of the empire, Constantinople, became an important center of artistic crafts. there were Byzantine jewelers. They managed to develop and qualitatively in a new way comprehend the traditions of Hellenistic and late antique jewelry art[133]. 
Unlike Byzantium, the development of the countries of Western Europe proceeded otherwise. The leading area of creativity in the Middle Ages remained architecture that influenced other activities. Gothic (XII-XV centuries) is the period of the highest flowering of medieval European culture and its final stage. The period from the beginning of the 15th to the middle of the 16th centuries. in the history of European culture represents the Renaissance [134]. The achievements of this era were most clearly manifested in Italy. However, in the field of making bronze casting of a decorative nature, the leading place belonged to French craftsmen. From the XIV century, the architects of the Renaissance inherited as a universal building material hewn natural stone and ordinary brick on lime mortar, in the role of the leading structure - a frame cross vault, a craft organization of construction work [135].

A common misconception is that the architects of the Italian Renaissance built mainly from natural cut stone and ordinary clay bricks. However, Choisy, examining the unfinished Italian buildings of that time, found that the core of the wall is very often made of concrete, but significantly different from the Roman one [136]. Due to the cross vault, the predominance of rectangular cells in the naves of cathedrals did not meet new needs and aesthetic ideas. Alberti motivated the advantages of a round and multifaceted shape practically by the fact that under this condition "it is very easy to add a lot of chapels", and theoretically - by referring to the fact that "nature pleases the round and hexagonal most of all" (in Fig.2).
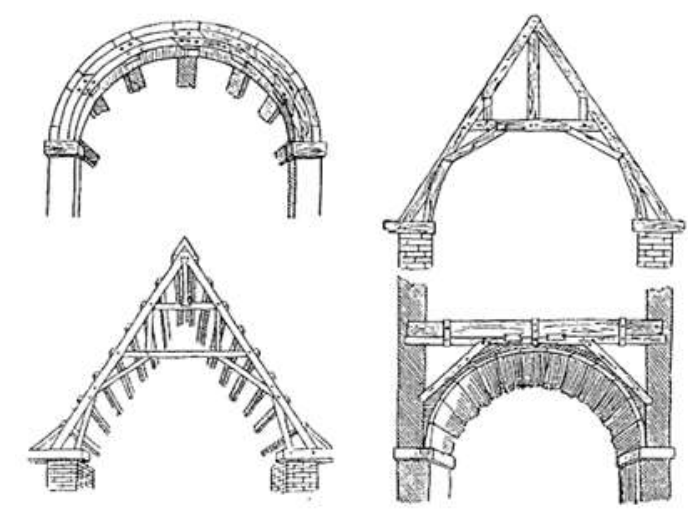

Figure 2. Construction machinery of the Renaissance in Italy.

All this prompted the architects of the Renaissance to prefer the ancient Roman dome, which was thoroughly forgotten in the Middle Ages, as the leading structure, 
leaving only an auxiliary role for the cross vault. The combination of the author and the performer in one person, characteristic of the craft, as well as the cooperation of equal, equally qualified craftsmen under the captious control of the workshop, impeded the grandiose construction of the era. Alberti essentially formulated the principles of manufacturing construction work. "The hand of an artisan," he says, "serves only as a tool for the architect," and recommends "finding clever, prudent, indefatigable assistants who will diligently, and unremittingly take care of everything necessary".

Instead of high-quality crushed stone, ordinary gravel was used here, instead of alternating masonry of leveled layers of mortar and crushed stone rammed into the solution, the components were simply thrown in a mess, without their preliminary mixing. Exactly so, according to the theorist of the late 18th and early 19th centuries. Rondela, the walls of the Cathedral of St. Peter in Rome.

Ordinary gravel, together with lime mortar, is randomly thrown into the formwork - cladding of travertine and bricks. Naturally, the question arises, for what reasons the architects of the Renaissance, borrowing architectural compositions and decor from the ancient Romans, did not borrow concrete either. In all likelihood, Roman concrete turned out to be of little use from an economic point of view for this era. What importance was attached to the cost of construction at that time can be seen from Barbaro's instructions that a cast column is cheaper than a stone one.

An important feature of the creative searches of Art Nouveau masters (end XIX - early XX centuries) was their conscious focus on creating synthetic works using the artistic possibilities of new designs of decorative plastic properties of materials, including non-traditional for art [137].

But compared to pouring gravel "mash" into stone formwork, which served at the same time as facing, the Roman technology was more laborious. Without requiring an increase in the number of workers with high-quality work engaged in masonry and backfilling, it was impracticable without a large number of laborers to beat crushed stone, level and ram components, etc. In the Middle Ages, customers, hiring craftsmen and apprentices, had the opportunity to use on construction of free unskilled labor, 
attracting it either in the order of feudal obligations, or with the promise of "absolution" (in Fig.3).

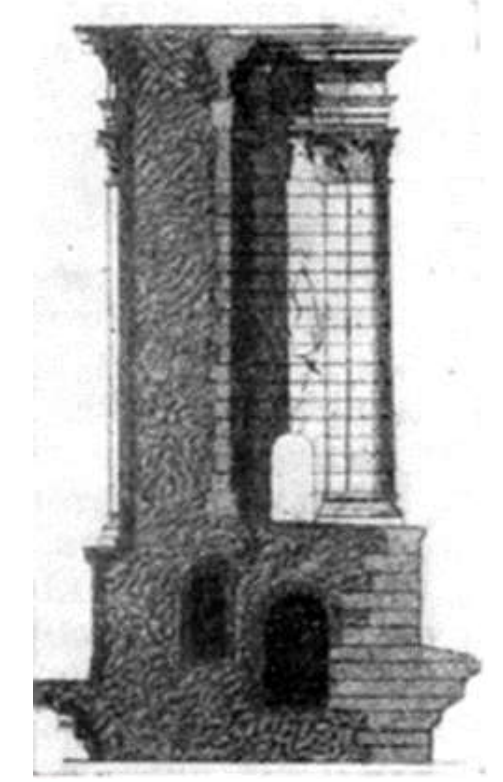

Figure 3. Concrete filling of the sinuses of the wall of the Cathedral of St. Peter in Rome.

The artist in his idea often proceeded from the metal processing technology, sometimes it was she who suggested to him the compositional solution. In the second half of the 20th century, interest in artistic forging reappeared. During mass industrial construction, the use of artistic metal was supposed to somewhat revive the overall picture. Artistic products of this period, as a rule, were made with blacksmith and metalwork tools. For the end of the XX century in the field of decorative and applied art, the creation of various compositions from geometric figures is characteristic.

The ergonomic properties of structures are assessed by the level of improvement in working conditions during its production in a progressive system. Quantitatively, this can be expressed in reducing the noise level at the workplace, facilitating transport operations by reducing weight, etc. This should also include improving the usability of the product by humans. The technological properties of the product include the "ability" of structures to be manufactured by the most productive method with the lowest economic costs, in compliance with environmental safety requirements.

The principles of the choice of material and technology for the manufacture of artificial products in their design from the standpoint of design can be formulated as 
follows: - the design of the designed product should not be lower than the design level of the prototype product; - compulsory compliance with the requirements of environmental safety, regulated by the current sanitary and hygienic standards, and the principles of environmental morality; - increasing economic efficiency by reducing costs, increasing durability and reducing operating costs; - reducing labor costs and improving working conditions, increasing the comfort of the working environment; increased convenience in use and operation for humans; - the manufacture of facade hinged systems should not require the creation of fundamentally new means of production [137].

The subject-spatial environment is perceived as a manifestation of the existing and historically developed color culture. Currently, three main problems of color design have emerged: first, the need for scientific and methodological support for color design; the second is to identify the specifics of the design of the colorist of various objects; the third is the creation of an aesthetically optimal range of materials. Studies of the color characteristics of copper alloys were carried out in order to determine the dependence of the color change of the alloy on the amount of alloying elements introduced [138].

The concept of an integrated approach to solving practical problems in design has been developed. The principles of choice of material and manufacturing technology of structures and finishing materials from the standpoint of design are proposed. A system of properties and parameters of new materials in design has been developed. Based on the analysis of the patterns of development of materials science and metal technology, a scientifically grounded concept of the choice of materials and technology in the design and manufacture of products from artificial materials of a finishing nature has been developed. The features of the constructive properties of new materials in the design of constructive systems for the finishing and artistic direction have been investigated. The theoretical foundations for the selection and development of new modern materials and technologies for the design of structures with specified properties have been developed. 